\title{
A Plant Stem Inoculation Assay for Assessing Transmission of Phytophthora infestans from Potato Seed Tubers to Emerged Shoots
}

\author{
Dennis A. Johnson and Thomas F. Cummings, Department of Plant Pathology, Washington State University, Pullman 99164-6430
}

\begin{abstract}
Johnson, D. A., and Cummings, T. F. 2013. A plant stem inoculation assay for assessing transmission of Phytophthora infestans from potato seed tubers to emerged shoots. Plant Dis. 97:183-188.

A stem inoculation assay was developed to assess transmission of Phytophthora infestans from the base of belowground potato stems to emerged aboveground shoots. Sporangia of $P$. infestans subsequently developed on aboveground stems after belowground stems were inoculated with isolates BF05 (US 8 genotype), WA10.1 (US 24), and 110B (US 11) by (i) placing a filter paper square saturated with a spore suspension onto nonwounded belowground stem tissue, (ii) placing a filter paper square saturated with a spore suspension onto wounded belowground stem tissue, and (iii) dipping the base of the cut belowground stem into a spore suspension. Plant stems were then incubated in a humidity chamber at 10 to $21.5^{\circ} \mathrm{C}$ for 7 to 28 days. Incidence of aboveground stems with sporulation was significantly less when stems were

inoculated with isolate 110B than with isolates BF05 and WA10.1 but length of latent period did not differ among the three isolates. Incidence of aboveground stems with sporangia was significantly $(P<$ $0.05)$ greater for 'Russet Norkotah' than for 'Umatilla Russet' when inoculated near the point of seed piece attachment. Incidence of aboveground stems with sporulation did not differ among incubation temperatures of 10,15 , and $21.5^{\circ} \mathrm{C}$. Latent period significantly increased as temperature decreased. Age of stem did not appear to affect incidence of transmission. Incidence of transmission of $P$. infestans to aboveground stems from the base of belowground stems was significantly lowered when aboveground stems were treated with selected fungicides $1 \mathrm{~h}$ before inoculation.
\end{abstract}

Phytophthora infestans (Mont.) de Bary, the cause of potato late blight, survives in infected tubers which may act as an inoculum source the following season (23). Oospores are not currently known to be a factor in overwintering of $P$. infestans in the Columbia Basin of Oregon and Washington; thus, a continuum of viable host tissue is essential for overwintering and transmission of $P$. infestans to new plant tissues $(23,27)$. Infected tubers are considered to be the main means for survival of the pathogen from season to season. Infected tubers serving as primary sources of inoculum after an overwintering period may be (i) refuse potato tubers and tare dirt, (ii) potato tubers left in the field after harvest that produce volunteer plants, and (iii) potato seed tubers $(2,4,8,20,27)$. The relative roles of these three primary inoculum sources in initiating epidemics varies and depends in part on microclimates, management tactics, and the extent of infection the previous growing season $(4,8,25,26)$. Each of the three primary inoculum sources has given rise to late blight epidemics in the semiarid, sprinkler-irrigated Columbia Basin (16). The role of infected seed tubers may have been underestimated (26) and their importance is being further evaluated, with the recent finding that seed tubers may be latently infected during long-term cold storage (17). Latent infection in seed tubers increases the potential of transmission from tubers to emerged shoots and contributes to the difficult nature of managing potato late blight.

Corresponding author: D. A. Johnson, E-mail: dajohn@wsu.edu

PPNS number 0596, Department of Plant Pathology, College of Agricultural, Human, and Natural Resource Sciences Agricultural Research Center, project number WNPO 0678, Washington State University, Pullman 991646430 .

Accepted for publication 29 August 2012.

http://dx.doi.org/10.1094/PDIS-06-12-0561-RE

(C) 2013 The American Phytopathological Society
Transmission of $P$. infestans from infected tubers to plant tissues may occur during seed-tuber handling, during cutting and planting, or in the field. The potential for one or more cycles of infection has been demonstrated when seed tubers are handled and cut (22). For secondary infection to occur during cutting and handling, the pathogen must survive in intact tubers in storage or during the winter, sporulate, be dispersed, and infect additional tubers or infest soil where plants are later infected $(15,21)$. P. infestans produces sporangia on tubers, and sporulation has been documented to occur within $19 \mathrm{~h}$ after seed tubers with late blight symptoms were removed from cold storage to a warmer environment at high humidity (24). Sporangia can be readily transmitted by direct contact from sporulating seed tubers or seed pieces to noninfected cut seed pieces (7), and sporangia deposited on eyes of seed tubers can infect the seed piece when planted (15). Infections during seedtuber cutting and handling likely increase the threat of late blight outbreaks on foliage in the field by serving as a primary source of inoculum. Fungicide seed piece treatments reduce transmission on seed tubers $(14,25)$.

$P$. infestans spreads asymptomatically by mycelial growth from infected seed tubers to shoots, advancing contiguously by following growing shoots $(5,23)$. This pathway was confirmed when $P$. infestans was detected in asymptomatic shoots emerging from infected tubers with the aid of the polymerase chain reaction $(1,12)$ and by inducing late blight symptoms and sporulation on emerged, asymptomatic shoots that arose from infected seed tubers (15). Furthermore, moist periods promoted symptom development on latently infected shoots arising from infected seed tubers, as well as favored production of sporangia. Healthy-appearing shoots developed late-blight symptoms during a $24-$ to 48 -h mist period or within a day after shoots were exposed to a wet period (15).

Because latent infections in tubers and emerging shoots pose an additional challenge in managing late blight, a plant assay would be useful in quantifying environmental, biological, chemical, and genetic effects on transmission of $P$. infestans from seed tubers to emerged shoots. The purpose of this research was to develop a 
stem inoculation assay to assess transmission of $P$. infestans from the base of belowground stems to aboveground stems and to use the assay to evaluate the effects of pathogen genotype, potato cultivar, temperature, stem age, and fungicides on late blight transmission.

\section{Materials and Methods}

Greenhouse. Certified seed tubers were planted 7 to $8 \mathrm{~cm}$ deep in 3-liter pots in a potting mix (LC1 Soil Mix; Sun Gro Horticultural, Canada Ltd.) in a greenhouse. Cultivars used were 'Russet Burbank', 'Ranger Russet', 'Russet Norkotah', and 'Umatilla Russet'. Plants were grown to approximately 15 to $20 \mathrm{~cm}$ in height. Plant stems were carefully removed from the pots and the potting mix. Plant stems were removed from the seed tubers at the point of attachment. Belowground stems were inoculated as described below. Above- and belowground stems were also contiguous during the entire assay, in that they were never cut or separated.

Isolates and inoculum. Isolates of $P$. infestans BF05 (US-8, A2 mating type), WA06 (US-8), WA10.1 (US-24, A1 mating type), and 110B (US-11 isolate, A1 mating type) were used in these studies. Isolate BF05 was collected from infected potato foliage obtained from Bonners Ferry, ID in 2005; isolates WA06 and WA10.1 were collected from infected potato foliage obtained from the Columbia Basin in Washington in 2006 and 2010, respectively; and isolate $110 \mathrm{~B}$ was collected from hairy nightshade near Mount Vernon, in western Washington, in 1996 (6). Isolates were maintained on rye agar medium at $18^{\circ} \mathrm{C}$ or in inoculated tubers of Russet Burbank that were stored at $5^{\circ} \mathrm{C}$. Isolate inoculum was increased on detached leaflets placed on a fiberglass screen over moistened paper towels in sealed glass container, 22.5 by $33 \mathrm{~cm}$ in size and 2.8 liter in volume, and incubated in the dark at $15^{\circ} \mathrm{C}$. Sporangia were washed from sporulating lesions on the leaflets, and the resultant sporangial suspension was adjusted to $1 \times 10^{4}$ sporangia/ml using a hemacytometer. The spore suspension was chilled at $4{ }^{\circ} \mathrm{C}$ for approximately $2 \mathrm{~h}$ to promote formation of zoospores unless otherwise stated as being not chilled. Inoculations were done with isolate BF05 except where noted.

Inoculation of belowground stems. Belowground stems were inoculated with $P$. infestans within $30 \mathrm{~min}$ of removal from the seed piece by one of three methods. With the first method, a $1-\mathrm{cm}^{2}$ piece of filter paper was dipped in a sporangium suspension of $P$. infestans, then applied to the base of the belowground stem near the point of seed piece attachment. We estimated that the filter paper square became water saturated with approximately $0.05 \mathrm{ml}$ of the spore suspension. The belowground stem was not wounded. The second method was the same as the first, except an approximately 3-by-5-mm area of the belowground stem was wounded near the point of seed attachment using a single light stroke with a flamed scalpel, at the place the filter paper square saturated with the spore suspension was soon placed. With the third method, the base of the belowground stem was cut just with sterile scissors above the point of attachment to the seed piece attachment and then dipped to a depth of $1 \mathrm{~cm}$ into a spore suspension $(10,000$ sporangia/ml) of $P$. infestans for approximately $1 \mathrm{~min}$. The inoculated stems were then placed on a fiberglass screen over moistened paper towels in a sealed glass container and incubated. Glass con- tainers were 22.5 by 33 by $6 \mathrm{~cm}$ ( 2.8 liter) or 28 by 38 by $6 \mathrm{~cm}$ ( 5 liter).

Stems were observed daily, unless other otherwise stated, for discoloration, lesions, and sporulation of $P$. infestans until sporulation occurred or for 4 weeks. Lesions were only considered to be caused by $P$. infestans if typical sporangia of the oomycete were observed. Incidence of aboveground stems with sporangia and length of latent period were determined. Latent period was the time between inoculation and the first appearance of sporangia.

Preliminary transmission tests. Transmission of $P$. infestans from belowground to aboveground stems was preliminarily evaluated for each of the three inoculation methods in seven separate tests. Belowground stems of Russet Norkotah, Russet Burbank, or Umatilla Russet were inoculated with either isolate BF05 or WA06, where the number of belowground stems inoculated was four to eight (Table 1). Five stems were used as the noninoculated controls (wounded or not wounded) in three tests and received distilled water on a filter paper square or were dipped in distilled water (Table 1). The seven trials were established to demonstrate transmission from the lower belowground stem to the aboveground stem, and not to test differences among inoculation methods, cultivar, or isolate.

Isolate tests. Transmission from belowground to aboveground stems was evaluated with isolates BF05, WA10.1, and the US-11 in stems of Russet Norkotah in trials using two methods of inoculation described previously. With the first method, stems were inoculated by placing a saturated filter paper square at the base of the belowground stem. Four stems as replicates were inoculated with each of the three isolates in a completely randomized design in three replicated trials. With the second inoculation method, stems were inoculated by dipping the base of a cut belowground stem into a sporangium suspension. Four stems were inoculated with each of the three isolates in a completely randomized design in two replicated trials. Stems inoculated with both methods were incubated in the dark at $15^{\circ} \mathrm{C}$ either until sporulation occurred on the aboveground stem or for 4 weeks.

Cultivar tests. Transmission from belowground to aboveground stems was evaluated in stems of Russet Norkotah, Russet Burbank, and Umatilla Russet. Inoculation was done by placing a filter paper square saturated with isolate BF05 at the nonwounded base of the belowground stem. Four stems as replicates of each cultivar were inoculated in a completely randomized designed. The trial was repeated.

Incubation temperature tests. Transmission from belowground to aboveground stems was evaluated at 15 and $21.5^{\circ} \mathrm{C}$ for Umatilla Russet and at 10,15 , and $21.5^{\circ} \mathrm{C}$ for Russet Burbank. Inoculation was done by cutting the belowground stems near the seed piece attachment and dipping the stem base into a spore suspension of isolate BF05. The spore suspension was either chilled or not chilled for the 15 and $21.5^{\circ} \mathrm{C}$ temperature treatments for both cultivars and was only chilled for the $10^{\circ} \mathrm{C}$ temperature treatment for Russet Burbank. Treatments of cultivar, temperature, and chilled or not chilled inoculum were arranged as a factorial design with four replicates in a completely randomized design. The trial was repeated. In a third trial, belowground stems of Umatilla Russet were inoculated with a sporangium suspension that was chilled, and

Table 1. Mean incidence of sporulation on aboveground stems and length of latent period when two cultivars were inoculated near the point of seed piece attachment of belowground stems with one of two isolates of Phytophthora infestans

\begin{tabular}{lllccc}
\hline Cultivar & Isolate & Inoculation method & $\begin{array}{c}\text { Number of belowground } \\
\text { stems inoculated }\end{array}$ & $\begin{array}{c}\text { Incidence of } \\
\text { sporulation (\%) }\end{array}$ & $\begin{array}{c}\text { Latent period in days: } \\
\text { mean (range) }\end{array}$ \\
\hline Russet Norkotah $^{\mathrm{z}}$ & BF05 & No wound, filter paper & 6 & 33 & $16(12-19)$ \\
Russet Norkotah $^{\mathrm{z}}$ & BF05 & Wound, filter paper & 5 & 100 & $12(11-13)$ \\
Russet Burbank $^{\mathrm{z}}$ & BF05 & Wound, filter paper & 4 & 50 & $12(9-15)$ \\
Russet Norkotah $^{\mathrm{z}}$ & BF05 & Cut base, dip & 4 & 100 & $10(9-11)$ \\
Umatilla Russet $_{\text {Russet Norkotah }}$ & BF05 & Cut base, dip & 8 & 38 & $27(26-28)$ \\
Umatilla Russet $^{\text {WA06 }}$ & WA06 & Cut base, dip & 8 & 63 & $16(10-24)$ \\
\hline
\end{tabular}

${ }^{\mathrm{z}}$ Number of noninoculated control stems was five; no visible symptoms were observed. 
stems were incubated at all three temperatures. Treatments were arranged as a completely random design with four replicates. Incidence of aboveground stems with sporangia and length of latent period were determined for the three trials.

Growth stage tests. Transmission from belowground to aboveground stems was evaluated in stems of two different growth stages of Umatilla Russet and Russet Burbank. Seed pieces of certified tubers were planted 3 weeks apart and grown in a potting mix in the greenhouse. Stems were removed from pots and inoculated at tuber initiation for the earlier planting. Mean stem height of aboveground stems was $35 \mathrm{~cm}$ for the earlier planting (older stems) and $25 \mathrm{~cm}$ in the later planting (younger stems, prior to tuber initiation). The bottoms of the belowground stems were cut just above the attachment to the seed piece and dipped into a spore suspension of $P$. infestans. Inoculated stems were incubated at $15^{\circ} \mathrm{C}$ as described above as a completely randomized design of four replicates. The trial was repeated.

Fungicide efficacy tests. Transmission from belowground to aboveground stems was evaluated when aboveground stems were treated with fungicide in five trials. In each, plants of Russet Norkotah were grown in the greenhouse to approximately $15 \mathrm{~cm}$ in height, treated with a selected fungicide, and then dried for $1 \mathrm{~h}$ in the greenhouse. Plant stems were then carefully removed from the pots so that the potting mix separated from the lower stems and seed tuber. The plant stems were removed at the attachment from the seed piece. The bottoms of the lower stems were then cut and dipped into a spore suspension of isolate BF05. The inoculated stems were then incubated on a fiberglass screen over moistened paper towels in a sealed glass container. Observations for sporulation were made 7 to 12 days after inoculation. Fungicide treatments were arranged as a completely randomized design with 4,8 , 5,5 , and 5 replications, respectively, in the five trials.

Fungicides and rates used in the tests were famoxidone, $25 \%$ at $585 \mathrm{ml} / \mathrm{ha}$ (E.I. du Pont de Nemours); ethylenebisdithiocarbamate (EBDC), $58.1 \%+$ manganese ${ }^{++}, 15.0 \%+$ zinc $^{++}, 1.9 \%$ (Manzate Pro-Stick) at $1.68 \mathrm{~kg}$ a.i./ha (E.I. du Pont de Nemours); dimethomorph, $43.9 \%$ (Forum) at $219 \mathrm{~g}$ a.i./ha (BASF Corp.); ametoctradin, 27.0\% + dimethomorph, 20.3\% (Zampro) at $537 \mathrm{~g}$ a.i./ha (BASF Corp.); difenoconazole, 21.9\% + mandipropamid, $21.9 \%$ (Revus Top) at $124 \mathrm{~g}$ a.i./ha (Syngenta Inc.); DPXGQU42 SC (experimental product) at $176 \mathrm{ml} / \mathrm{ha}$ (E.I. du Pont de Nemours); and DPXGQU42 EC, 10\% EC formulation (experimental product) at $176 \mathrm{ml} / \mathrm{ha}$ (E.I. du Pont de Nemours).

Statistical analysis. Data for incidence of aboveground stems with sporangia and length of latent period for the first five trials are summarized in Table 1, and were not statistically analyzed. The trials were done separately and only to demonstrate transmission from the lower belowground stem to the aboveground stem for that particular inoculation method. Data for incidence of aboveground stems with sporangia and length of latent period in subsequent trials were analyzed by analysis of variance (ANOVA) using PROC GLM of SAS (release 9.1; SAS Institute Inc.). Fisher's protected least significant difference at $P=0.05$ was used to compare treatments.

Data were analyzed as a completely randomized design by a single-factor ANOVA for the trials where isolates and cultivars were evaluated. For isolates, a significant interaction between trials and isolates was not found; the three trials using the filter paper method of inoculation were combined and the two trials using the cut and dip method of inoculation were combined. Data for the repeated trials where cultivars were evaluated were combined because there was not a significant difference between repeated trials or trialfactor interaction $(P>0.05)$ for either incidence of aboveground stems with sporulation or latent period.

Data for incidence of stems with sporangia for the first two trials evaluating incubation temperature were analyzed separately as a completely randomized design with a two-factor ANOVA for Umatilla Russet and Russet Burbank because one of the cultivars, Umatilla Russet, was not incubated at one of three temperatures $\left(10^{\circ} \mathrm{C}\right)$. Data for incidence of stems with sporulation were com- bined because there was not a significant difference between repeated trials or any trial-factor interaction at $P=0.05$. Data for incidence of stems with sporulation for the third trial using only Umatilla Russet were analyzed using incubation temperature as a single factor in a completely randomized design.

The relationship of length of latent period (dependent variable) and incubation temperature (independent variable) was investigated with regression using PROC REG of SAS. Temperature data were transformed to the natural log to provide the best model for the data based on $P$ value and $R^{2}$. Data for Umatilla Russet and Russet Burbank in the first two trials were collected in 2010 and combined, and data for Umatilla Russet in the third trial were collected in 2011 and analyzed separately.

Data for the two trials evaluating stem age were analyzed as a completely randomized design. The two age trials were combined because there was not a significant interaction between trials or trial-treatment factors for either variable. However, cultivars were analyzed separately, because there was a significant cultivar-age interaction $(P=0.005)$ for incidence of stems with sporulation.

For the five trials where fungicide efficacy was evaluated, data were analyzed as a completely randomized design. The fourth and fifth trials were combined because they contained the same treatments and had no significant trial differences $(P>0.05)$ or treatment interactions $(P>0.05)$.

\section{Results}

Preliminary transmission tests. Sporangia of $P$. infestans developed on 20 to $100 \%$ of the aboveground stems when the belowground stems near the seed piece attachment were inoculated in seven trials (Table 1). Sporulation did not develop on noninoculated control stems. Sporangia were observed on aboveground stems 9 to 28 days after inoculation when stems were incubated at $15^{\circ} \mathrm{C}$ (Table 1). Lesions on aboveground stems often did not develop until after sporulation had occurred. Sporulation developed near the part of the stem originally at the soil line to several centimeters above the original soil line on aboveground stems (Fig. 1). The development of lesions and sporangia varied on belowground stems when sporulation occurred on aboveground stems. The variant expressions of disease symptoms on belowground tissues consisted of the following: (i) the belowground stem tissue remained white and did not develop lesions (sporulation occurred on aboveground stems), (ii) streaks of reddish-brown discoloration developed, (iii) a dark brown to black lesion developed on the lower portion of the belowground stems, and (iv) a dark brown lesion covered the entire belowground stem. Sporulation was often sparse or not present on belowground stems but sporangia then occurred more abundantly near and above the part of the stem originally at the soil line. Sporulation without the development of a distinct lesion or necrosis was sometimes observed to proceed up the

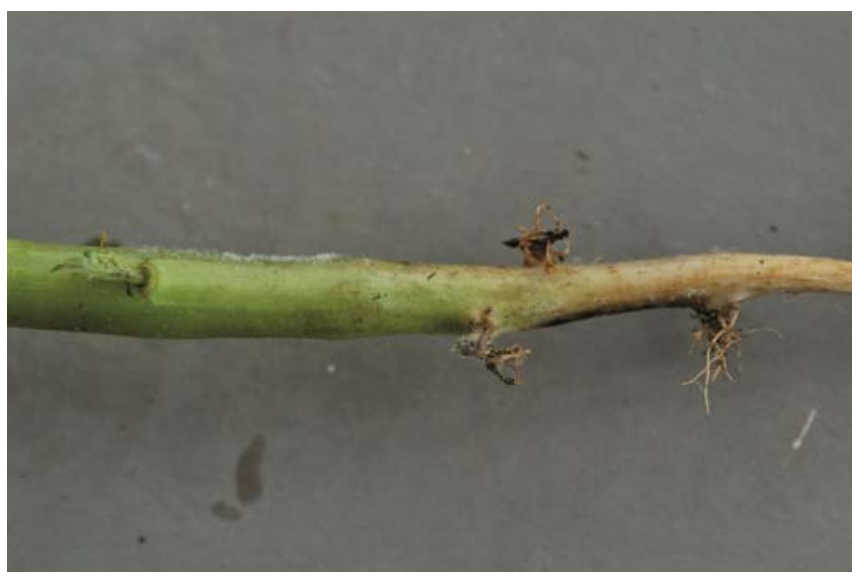

Fig. 1. Sporulation of Phytophthora infestans on an aboveground stem when the belowground stem was inoculated by cutting the stem near the seed piece attachment and dipping it in a suspension of sporangia and zoospores. 
belowground stem from the site of inoculation to the aboveground stem.

Isolate tests. Sporangia of $P$. infestans developed on aboveground stems when belowground stems were inoculated with isolates BF05, WA10.1, and 110B by placing a saturated filter paper square on nonwounded stem tissue and by dipping the base of the cut belowground stem into a spore suspension. Incidence of aboveground stems with sporangia was significantly less when belowground stems were inoculated with isolate 110B than the other two isolates but length of latent period did not differ among the three isolates for both methods of inoculation (Table 2).

Cultivar tests. Incidence of aboveground stems with sporangia was significantly $(P<0.05)$ greater for Russet Norkotah than for Umatilla Russet when belowground stems were inoculated near the seed piece attachment with a saturated filter paper square. Incidence of aboveground stems with sporangia on Russet Burbank was intermediate to that of Russet Norkotah and Umatilla Russet (Table 3$)$. Length of latent periods did not differ $(P>0.05)$ among the three cultivars (Table 3 ).

Incubation temperature tests. Incidence of aboveground stems with sporangia and length of latent period did not differ when belowground stems where inoculated with either chilled or nonchilled sporangium suspensions. Incidence of aboveground stems with sporangia did not differ among incubation temperatures of 10,15 , and $21.5^{\circ} \mathrm{C}$ and between Russet Burbank and Umatilla Russet in the first two trials $(P>0.05$; Table 4). Incidence of aboveground stems with sporangia did not differ among incubation temperatures of 10,15 , and $21.5^{\circ} \mathrm{C}$ for Umatilla Russet in the third trial $(P>0.05$; Table 4). Latent period significantly increased as temperature decreased when analyzed with regression for the first two trials involving Russet Burbank and Umatilla Russet (Fig. 2; $P<0.0001, R^{2}=0.88$ ) and in the third trial for Umatilla Russet (Fig. 2.; $P<0.0001, R^{2}=0.88$ ).

Growth stage test. Incidence of aboveground stems with sporangia and length of latent period did not differ when stems were inoculated at the two different growth stages (Table 5). A significant

Table 2. Mean incidence of sporulation on aboveground stems when the base of belowground stems near the point of seed piece attachment of 'Russet Norkotah' were inoculated with either a nonwounding or wounding inoculation technique with one of three isolates of Phytophthora infestans and incubated at $15^{\circ} \mathrm{C}^{\mathrm{x}}$

\begin{tabular}{lccccc}
\hline & \multicolumn{2}{c}{ No wound, filter paper } & & \multicolumn{2}{c}{ Wound, cut $^{\mathbf{y}}$ Isip } \\
\cline { 2 - 3 } \cline { 5 - 6 } Isolate & IS $(\%)$ & LP & & IS (\%) & LP \\
\hline BF05 & $64 \mathrm{a}$ & $13.4 \mathrm{a}$ & & $100 \mathrm{a}$ & $9.3 \mathrm{a}$ \\
WA10.1 & $55 \mathrm{a}$ & $15.3 \mathrm{a}$ & & $100 \mathrm{a}$ & $10.9 \mathrm{a}$ \\
110B & $9 \mathrm{~b}$ & $14.0 \mathrm{a}$ & & $75 \mathrm{~b}$ & $10.0 \mathrm{a}$ \\
\hline
\end{tabular}

${ }^{\mathrm{x}}$ IS $=$ incidence of sporulation and $\mathrm{LP}=$ latent period. Values followed by the same letter within a column for each category are not significantly different at $P=0.05$ according to Fisher's protected least significant difference.

${ }^{\mathrm{y}}$ Values are means of four replicates in two trials and three replicates in a third trial, total $n=11$.

${ }^{\mathrm{z}}$ Values are means of four replicate in each of two trials, total $n=8$.

Table 3. Incidence of sporulation on aboveground stems and length of latent period when belowground stems of three cultivars were inoculated with Phytophthora infestans by placing a filter paper square saturated with a sporangium suspension on nonwounded tissue near the point of seed piece attachment ${ }^{\mathrm{y}}$

\begin{tabular}{lcc}
\hline Cultivar & Incidence (\%) & Latent period (days) $^{\mathbf{z}}$ \\
\hline Russet Norkotah & $100 \mathrm{a}$ & 12.3 \\
Russet Burbank & $63 \mathrm{ab}$ & 12.8 \\
Umatilla Russet & $38 \mathrm{~b}$ & 13.7 \\
\hline
\end{tabular}

y Values are a mean of four replicates for each of two trials. Values followed by the same letter within a column for each category are not significantly different at $P=0.05$ according to Fisher's protected least significant difference.

${ }^{\mathrm{z}}$ Length of latent period did not differ significantly among cultivars. interaction $(P=0.005)$ between growth stage and cultivar resulted for incidence of sporulation (Table 5) in that a higher incidence of stems with sporulation occurred on stems inoculated prior to tuber initiation for Umatilla Russet but not for Russet Burbank.

Fungicide efficacy tests. Incidence of aboveground stems with sporulation of $P$. infestans was significantly less than the inoculated control on stems treated with either GQU42EC or GQU42SC in five of five trials and with mandipropamid + difenoconazole in four of five trials (Table 6). Incidence of aboveground stems with sporulation of $P$. infestans did not differ significantly from the nontreated inoculated control on stems treated with mancozeb, famoxate, dimethomorph, and ametoctradin + dimethomorph (Table 6).

\section{Discussion}

Transmission of $P$. infestans from the base of belowground stems to aboveground stems was demonstrated using a plant stem inoculation assay. Belowground stems were inoculated near the point of attachment to the seed piece on both wounded and nonwounded tissue. Sporangia of $P$. infestans usually developed on stems near or above the soil line after a latent period. However, sporulation also developed several centimeters above the part of the stem at the original soil line. The same results were observed when transmission of $P$. infestans was recently documented from infected seed tubers to emerged potato sprouts in a soil environment (15), thus confirming the validity of the plant stem inoculation assay.

Table 4. Incidence of sporulation on aboveground stems when the base of belowground stems of 'Umatilla Russet' and 'Russet Burbank' were inoculated with chilled and nonchilled sporangia of Phytophthora infestans near the seed piece attachment and then incubated at three temperatures in two trials and stems of only Umatilla Russet in a third trial

\begin{tabular}{lccc}
\hline & \multicolumn{3}{c}{ Incidence of sporulation (\%) } \\
\cline { 2 - 4 } & $\mathbf{1 0}^{\circ} \mathbf{C}$ & $\mathbf{1 5 . 0}^{\circ} \mathbf{C}$ & $\mathbf{2 1 . 5}^{\circ} \mathbf{C}$ \\
\hline Trials I and II combined & & & \\
Umatilla Russet & $\mathrm{y}$ & & \\
$\quad$ Chilled & $\ldots$ & 63 & 88 \\
$\quad$ Nonchilled & $\ldots$ & 100 & 75 \\
$\quad$ Russet Burbank & & & \\
$\quad$ Chilled & & 75 & 100 \\
$\quad$ Nonchilled & 63 & 75 & 88 \\
Trial III & $\ldots$ & & \\
$\quad$ Umatilla Russet & & & \\
$\quad$ Chilled & 75 & 100 & 75 \\
\hline
\end{tabular}

y Values are means of four replicates for each of two trials. Percentage of infected stems did not differ significantly between chilled and nonchilled sporangium suspension and among temperatures.

${ }^{z}$ Values are means of four replicates for one trial.

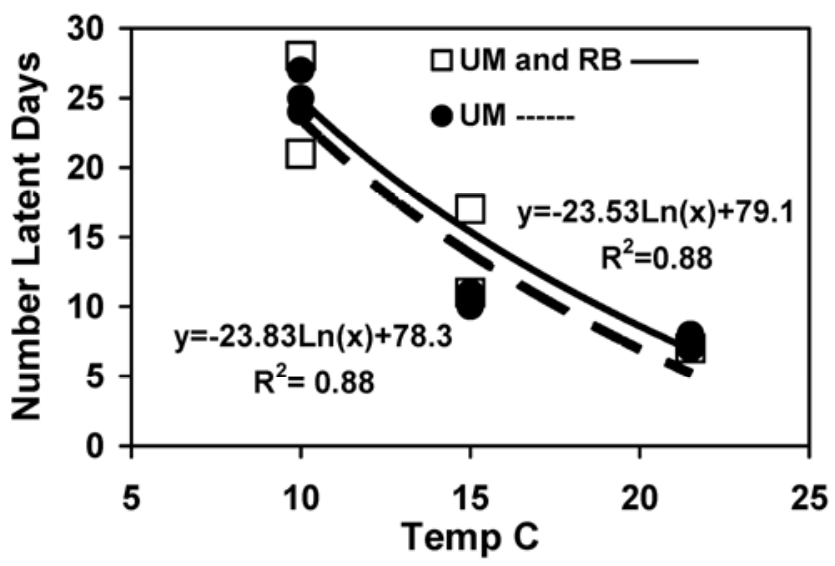

Fig. 2. Length of latent period required for production of sporangia on aboveground stems in relation to temperature when belowground stems of 'Russet Burbank' (RB) and 'Umatilla Russet' (UM) were inoculated with Phytophthora infestans in two trials and Umatilla Russet in a third trial. 
Sporangia developed on aboveground stems using each of the three inoculation techniques. The inoculation methods were similar and were not directly compared. The main difference was whether or not the belowground stems were wounded. Incidence of infection was high when the three isolates were evaluated using the cut and dip method relative to the filter paper square method of inoculation. Dipping the bottom of a cut belowground stem in a spore suspension allowed spores to be exposed to internal tissues. Mycelium could then grow within the stem. P. infestans had to penetrate and colonize the surface of the stem when inoculated by placing a saturated filter paper square on the stem surface.

The development of tissue discoloration and sporangia on belowground stems varied on stems that yielded sporangia on the aboveground stems. Sporangia sometimes developed on aboveground stems without the expression of a necrosis or discoloration on the belowground stem. Lesions often did not develop on belowground stems when the base of the inoculated stem was not wounded but a lesion frequently occurred on belowground stems when wounded for inoculation. Wounding would naturally open avenues for secondary infection by bacteria which could increase discoloration on the stem. In the field, the degree of infection and presence of secondary bacteria in the seed piece may affect the development of symptoms on belowground stems. The varied expression of disease development, especially the latent development of sporulation, adds to the difficulty of recognizing infections from seed pieces.

Transmission of $P$. infestans occurred with each of the three genotypes tested. A difference among the isolates was expected (26) and transmission was more efficient for the US8 and US24 isolates than the US1 isolate. However, the number of isolates tested was small. More isolates need to be evaluated, especially from infected seed tubers, before conclusions can be made about the efficiency of transmission of a particular genotype. The 110B isolate (US11 genotype) was originally obtained from infected black nightshade (6) but has been aggressive on potato in several previous experiments $(6,13,19)$.

Table 5. Incidence of sporulation on aboveground stems when the base of belowground stems of 'Umatilla Russet' and 'Russet Burbank' were inoculated near the point of seed piece attachment at two different growth stages with Phytophthora infestans and incubated at $15^{\circ} \mathrm{C}^{\mathrm{z}}$

\begin{tabular}{lcc}
\hline Stage & $\begin{array}{c}\text { Incidence of } \\
\text { sporulation }(\%)\end{array}$ & $\begin{array}{c}\text { Length of latent } \\
\text { period (days) }\end{array}$ \\
\hline $\begin{array}{l}\text { Umatilla Russet } \\
\text { Prior to tuber initiation }\end{array}$ & $100 \mathrm{a}$ & $17.8 \mathrm{a}$ \\
At tuber initiation & $63 \mathrm{~b}$ & $18.3 \mathrm{a}$ \\
Russet Burbank & $50 \mathrm{~b}$ & $10.8 \mathrm{~b}$ \\
Prior to tuber initiation & $100 \mathrm{a}$ & $13.0 \mathrm{~b}$ \\
At tuber initiation & & \\
\hline
\end{tabular}

${ }^{z}$ Values are mean of four replicates for each of two trials. Values followed by the same letter within a column for each category are not significantly different at $P=0.05$ according to Fisher's protected least significant difference. Percentage of aboveground stems with sporangia did not vary significantly between growth stages or between cultivars at $P=0.05$.
Incidence of transmission was greater for Russet Norkotah than for Umatilla Russet in this study. Additional cultivars need to be evaluated for susceptibility and resistance to transmission. Cultivars ultrasusceptible to transmission may be a factor in promoting late blight epidemics, and resistant cultivars would retard epidemics. Length of latent period for the time between inoculation and sporulation did not significantly differ among Russet Norkotah, Russet Burbank, and Umatilla Russet. Length of latent period increased as incubation temperature decreased. Length of latent period may also be influenced, in part, by the length of belowground stem, which is determined by planting depth. In general, shorter belowground stems would require less time for $P$. infestans to grow from the infected seed piece to the aboveground stem.

Accurately forecasting the potential for transmission from infected seed tubers would be valuable in managing potato late blight. However, variation in length of latent period was evident during these experiments, with mean latent period ranging from 12 to 27 days at $15^{\circ} \mathrm{C}$ during incubation (Tables $1-5$ ). The variation in length of latent period would make prediction for time of transmission difficult. Considering the survivability of the pathogen, variation in latent period allows $P$. infestans the ability to potentially produce initial inoculum from infected tubers over a relatively longer period of time, thus giving the pathogen an increased opportunity to survive and to initiate epidemics during favorable weather.

Inoculated belowground stems exhibited tissue with light to dark brown discoloration, with the darkest brown discoloration near the inoculation site. However, reddish-brown streaking or no discolored tissue was often observed on inoculated belowground stems. Necrotic tissue did not always occur on the belowground stems, especially when inoculated without wounding. Evidently, $P$. infestans can grow internally up belowground stems without showing symptoms. Wounding the inoculated stem increases the likelihood of secondary infections that may cause necrosis. Any secondary bacterial infections of late-blight-infected seed tubers would also likely result with necrosis of belowground stems when transmission of $P$. infestans occurs from the seed tuber. A continuous lesion from the seed piece to the aboveground stem lesion was not observed to be present in some instances of transmission in a previous study (26).

Necrosis of the belowground stem was once thought to indicate mycelial continuity between the lesion on the stem and its parent tuber. The lack of belowground stem lesions has been used as an indication that transmission from seed tubers has not occurred (11). Because belowground lesions do not always occur when seed tubers are the source of transmission, early researchers were misled in their assessment of the relative importance of various origins of late blight epidemics. Invaded stems are usually weak and are killed when girdled or blighted by $P$. infestans; therefore, it is not surprising how rarely they can be found among the multitude of healthy stems from over 29,650 tubers planted per hectare. Most attempts have failed to overcome the dilemma described by Brooks in1919 (3) and repeated by Hirst and Stedman (11) that, "by the time a group of plants more heavily infected than the rest of the

Table 6. Incidence of sporulation on aboveground stems after foliage of 'Ranger Russet' (R), 'Russet Burbank' (RB), or 'Russet Norkotah' (N) was treated with various fungicides and then stems were removed from the pot and the base of belowground stems were cut and dipped in a spore suspension of Phytophthora infestans, then incubated at $21^{\circ} \mathrm{C}$ for 10 days ${ }^{\mathrm{z}}$

\begin{tabular}{lcccc}
\hline Treatment & First trial $(\mathbf{R})$ & Second trial (RB) & Third trial (RB) & Fourth and fifth trials (N) \\
\hline Control & $75 \mathrm{a}$ & $50 \mathrm{a}$ & $80 \mathrm{a}$ & $100 \mathrm{a}$ \\
Mancozeb & $\ldots$ & $\ldots$ & $\ldots$ & $\ldots$ \\
Famoxate & $50 \mathrm{ab}$ & $25 \mathrm{ab}$ & $\ldots$ & $800 \mathrm{a}$ \\
Dimethomorph & $\ldots$ & $0 \mathrm{~b}$ & $60 \mathrm{a}$ & $80 \mathrm{ab}$ \\
Ametoctradin + dimethomorph & $\ldots$ & $0 \mathrm{~b}$ & $40 \mathrm{ab}$ & $80 \mathrm{ab}$ \\
Mandipropamid + difenoconazole & $50 \mathrm{ab}$ & $0 \mathrm{~b}$ & $0 \mathrm{~b}$ & $\ldots$ \\
QGU42SC & $0 \mathrm{~b}$ & $0 \mathrm{~b}$ & $0 \mathrm{~b}$ & $20 \mathrm{c}$ \\
QGU42EC & $0 \mathrm{~b}$ & $0 \mathrm{~b}$ & \\
\hline
\end{tabular}

${ }^{z}$ Values are means of four replicates in trial 1, eight replicates for trial 2, and five replicates for trials 3 , 4, and 5 . Trials 4 and 5 were combined because they contained the same treatments and had no significant trial differences or treatment interactions. Values followed by the same letter within a column for each category are not significantly different at $P=0.05$ according to Fisher's protected least significant difference. 
crop is noticed, it is usually too late to decide how the infection originated". Tracing the origin of late blight epidemics to primary foci in commercial potato fields has been done to determine the relative importance of infected tubers serving as seed, volunteer potato plants, or culls $(11,27)$. Knowing the relative importance of these potential sources of late blight is epidemiologically important in that disease control tactics can then be directed at reducing the most likely sources.

High humidity during incubation was important for development of sporangia on aboveground stems during the inoculation assay. A mist period was demonstrated to promote transmission from infected seed tubers to emerged shoots (15). An association of rainfall and possible transmission from infected seed tubers was observed by Hirst and Stedman; however, the growth of $P$. infestans within stems was concluded not to be limited to wet weather (11). Effective transmission requires growth of $P$. infestans within stems and then sporulation on the aboveground stem. Sporulation on aboveground stems requires moist conditions (15).

The importance of seed tubers as a within-field source of inoculum for initiating late blight epidemics has often been underestimated and may be a more frequent occurrence than generally realized (26). In addition, epidemics initiated from infected seed tubers can be especially difficult to manage because infection foci may be randomly located and spread throughout a field (14). For example, nine fungicide applications were used over a 36-day period to manage late blight originating from infected seed tubers in a sprinklerirrigated field of Russet Norkotah in the semiarid environment of the Columbia Basin in 1998 (16). Latent infections in tubers and transmission from infected tubers to emerging shoots pose additional challenges and, perhaps, potential opportunities to manage late blight. An opportunity for improved management may exist if a control tactic can be applied to eliminate or restrict transmission.

The inoculation assay of belowground stems simulated transmission of $P$. infestans from infected seed tubers to the emerged shoot and may be a tool in evaluating fungicide efficacy in limiting transmission in the field. Two formulations of an experimental fungicide (QGU42SC and QGU42EC) applied to aboveground foliage were effective in limiting transmission of $P$. infestans from seed tubers in the inoculation assays. Fungicides with the ability to restrict sporulation and that have curative activities would be desired to limit transmission from infected seed pieces. Sporulation was inhibited on established lesions of foliar stems by dimethomorph plus mancozeb in a previous study (18) but dimethomorph by itself was not effective in inhibiting sporulation at the base of aboveground stems when the infection originated at the bottom of the belowground stem in this study. Additional tests are needed in the field to fully evaluate the efficacy of fungicides in restricting transmission form infected seed tubers to the emerged shoots.

Timely application of an effective fungicide early in the development of the potato crop may potentially be effective in reducing transmission of $P$. infestans from infected seed tubers to emerged shoots and, additionally, would be effective in preventing secondary cycles of infection, effectively delaying late blight epidemics. Earlyseason applications of fungicides have been suggested to limit transmission from seed pieces (26). A method of application would be needed to deposit fungicide at the base of plant stems $(9,10)$. Mancozeb and cymoxanil applied as seed-piece treatments were demonstrated to limit spread of $P$. infestans among seed tubers during cutting and handling $(14,25,26)$ but mancozeb was not effective in restricting transmission from the seed piece to the emerged shoot, as presently reported. This study demonstrated transmission of $P$. infestans from below- to aboveground stems and the potential effectiveness of selected fungicides in limiting transmission from infected seed pieces to emerged stems using a transmission assay.

\section{Acknowledgments}

We thank D. Inglis and L. Porter for critical presubmission reviews of the manuscript and D. Inglis for supplying isolate B110.

\section{Literature Cited}

1. Appel, R., Adler, N., and Habermeyer, J. 2001. A method for the artificial inoculation of potato tubers with Phytophthora infestans and polymerase chain reaction assay of latently infected sprouts and stems. J. Phytopathol. 149:287-292.

2. Boyd, A. E. W. 1974. Sources of potato late blight (Phytophthora infestans) in the east of Scotland. Plant Pathol. 23:30-36.

3. Brooks, F. T. 1919. An account of some field observations on the development of potato blight. New Phytol. 18:187.

4. Davidse, L. C., Henken, J., van Dalen, A., Jespers, A. B. K., and Mantel, B. C. 1989. Nine years of practical experience with phenylamide resistance in Phytophthora infestans in the Netherlands. Neth. J. Plant Pathol. 95 (Suppl. 1):197-213.

5. De Bary, A. 1876. Researches into the nature of the potato-fungus - Phytophthora infestans. J. R. Agric. Soc. 12:239-269.

6. Dorrance, A. E., Inglis, D. A., Derie, M. O., Brown, C. R., Goodwin, S. B. Fry, W. E., and Deahl, K. L. 1999. Characterization of Phytophthora infestans populations in western Washington. Plant Dis. 83:423-428.

7. Dowley, L. J., and O'Sullivan, E. 1991. Sporulation of Phytophthora infestans (Mont.) De Bary on the surface of diseased potatoes and tuber to tuber spread of infection during handling. Potato Res. 34:295-296.

8. Gigot, J. A., Gundersen, B., and Inglis, D. A. 2009. Colonization and sporulation of Phytophthora infestans on potato tubers under northwestern Washington conditions. Am. J. Potato Res. 86:1-14.

9. Hamm. P. B., Boydston, R. A., Hoy, C. W., , Stevenson, W. R., and Hutchinson, P. J. S. 2008. Applying pesticides. Pages 113-121 in: Potato Health Management, 2nd ed. D. A. Johnson, ed. American Phytopathological Society, St. Paul, MN

10. Hamm, P. B., Cummings, T. F., and Johnson, D. A. 2006. Comparison of deposition patterns in two programs for applying protectant fungicides to potato stems and leaves for the control of late blight (Phytophthora infestans). Am. J. Potato Res. 83:473-484.

11. Hirst, J. M., and Stedman, O. J. 1960. The epidemiology of Phytophthora infestans II. The source of inoculum. Ann. Appl. Biol. 48:489-517.

12. Hussain, S., Lees, A. K., Duncan, J. M., and Cooke, D. E. L. 2007 Development of a species-specific and sensitive detection assay for Phytophthora infestans and its application for monitoring of inoculum in tubers and soil. Plant Pathol. 54:373-382.

13. Inglis, D. A., Brown, C. R., Gundersen, B. G., Porter, L. D., Miller, J. S. Johnson, D. A., Lozoya-Saldana, H., and Haynes, K. G. 2007. Assessment of Solanum hougasii in Washington and Mexico as a source of resistance to late blight. Am. J. Potato Res. 84:217-228.

14. Inglis, D. A., Powelson, M. L., and Dorrance, A. E. 1999. Effect of registered potato seed piece fungicides on tuber-borne Phytophthora infestans. Plant Dis. 83:229-234.

15. Johnson, D. A. 2010. Transmission of Phytophthora infestans from infected potato seed tubers to emerged shoots. Plant Dis. 94:18-23.

16. Johnson, D. A., Alldredge, J. R., Hamm, P. B., and Frazier, B. E. 2003. Aerial photography used for spatial pattern analysis of late blight infection in irrigated potato circles. Phytopathology 93:805-812.

17. Johnson, D.A., and Cummings, T.F. 2009. Latent infection of potato seed tubers by Phytophthora infestans during long term cold storage. Plant Dis. 93:940-946.

18. Johnson, D. A., Cummings, T. F., and Geary, B. 2000. Postinfection activity of selected late blight fungicides. Plant Dis. 84:1116-1120.

19. Johnson, D. A., Inglis, D. A., and Miller, J. S. 2004. Control of potato tuber rots caused by oomycetes with foliar applications of phosphorous acid Plant Dis. 88:1153-1159.

20. Kadish, D., and Cohen, Y. 1992. Overseasoning of metalaxyl-sensitive and metalaxyl-resistant isolates of Phytophthora infestans in potato tubers. Phytopathology 82:887-889.

21. Kromann, P., Taipe, A., Andrade-Piedra, J. L., Munk, L., and Forbes, G. A. 2008. Preemergence infection of potato sprouts by Phytophthora infestans in the highland tropics of Ecuador. Plant Dis. 92:569-574.

22. Lambert, D. H., Currier, A. I., and Olanya, M. O. 1998. Transmission of Phytophthora infestans in cut potato seed. Am. J. Potato Res. 75:257263.

23. Melhus, I. E. 1915. Hibernation of Phytophthora infestans of the Irish potato. J. Agric. Res. 5:71-112.

24. Porter, L. D., Johnson, D. A., and Cummings, T. F. 2001. Development of Phytophthora infestans in potato tubers of nine clones in storage. (Abstr.) Phytopathology 91:S188.

25. Powelson, M. L., and Inglis, D. A. 1999. Foliar fungicides as protective seed piece treatments for management of late blight of potatoes. Plant Dis. 83:265-268.

26. Powelson, M. L., Ludy, R., Partipilo, H., Inglis, D. A., Gundersen, B., and Derie, M. 2002. Seed borne late blight of potato. Plant Health Progress. Online publication. doi:10.1094/PHP-2002-0129-01-HM

27. Zwankhuizen, M. J., Govers, F., and Zakoks, J. C. 1998. Development of potato late blight epidemics: disease foci, disease gradients, and infection sources. Phytopathology 88:754-763. 